\title{
Musculoskeletal Process
}

National Cancer Institute

\section{Source}

National Cancer Institute. Musculoskeletal Process. NCI Thesaurus. Code C41480.

A Musculoskeletal Process consists of a function of cellular, cell, or tissue components of the organ system comprised of muscle, bone, and cartilage. 